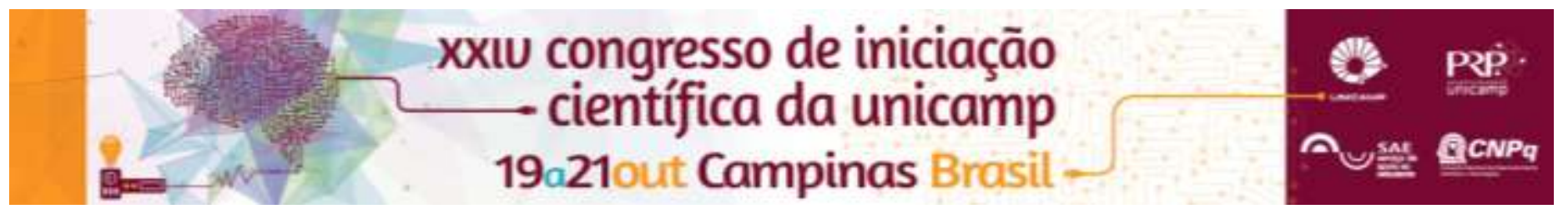

\title{
Diálogos Difíceis: o trabalho do músico em aulas de dança
}

\author{
Livia Carolina de Oliveira*, Jorge L. Schroeder
}

\section{Resumo}

Este trabalho investiga as relações profissionais, pedagógicas e artísticas que envolvem o trabalho dos músicos que tocam em aulas técnicas de dança. O foco principal da pesquisa é o Departamento de Artes Corporais da Unicamp. Os fundamentos teóricos da pesquisa se assentam na sociologia do trabalho, na sociologia reflexiva, na sociologia do trabalho imaterial e na filosofia da linguagem. Pretende-se, assim, problematizar as condições de um trabalho primeiramente tido como "criativo", mas que numa observação mais minuciosa se mostra envolvido numa lógica de trabalho passivo e repetitivo.

Palavras-chave: Música, dança, trabalho.

\section{Introdução}

A presente pesquisa é parte de uma pesquisa maior que investiga as relações entre música e dança, músicos e bailarinos, em situação educacional (na formação de bailarinos) e em situações artísticas (no trabalho colaborativo). Aqui nos concentramos na participação do músico de aulas de dança na formação dos bailarinos. Sendo supostamente um trabalho de caráter artístico, resolvemos investigar os efeitos educacionais e artísticos da presença dos músico tocando ao vivo em aulas técnicas de dança.

\section{Resultados e Discussão}

A partir da fundamentação teórica calcada em algumas premissas da sociologia do trabalho artístico de Liliana Segnini e das discussões sobre o trabalho imaterial, complementados pelas concepções da filosofia da linguagem e dos sistemas simbólicos, foi possível averiguar, por intermédio de entrevistas e da observação participativa, que: 1) sob o ponto de vista das professoras entrevistadas "a música fica respondendo às necessidades da dança" que se mostram bem específicas, bloqueando muitas vezes um diálogo mais criativo entre música e movimentos; 2) sob o ponto de vista das alunas entrevistadas em geral elas consideram a presença dos músicos ao vivo muito intensa e estimulante, contudo várias delas percebem certos descompassos entre as necessidades mais rígidas dos exercícios e as possibilidade mais criativas da presença dos músicos. Algumas se expressaram mais precisamente sobre a necessidade de terem mais contatos com a música fora das aulas de técnica, em aulas de música; 3) sob o ponto de vista dos músicos, parece haver um esforço no combate diário à "estagnação" das relações. Ou seja, tentam de algum modo atualizar suas formas de responder ao "esqueleto" rítmico imposto pelos exercícios, "vesti-los com outras roupas" para que não haja a cristalização biunívoca das relações: certos exercícios específicos com certas músicas específicas (como é o caso do balé clássico).

\section{Considerações finais}

São complexas e ainda mal compreendidas as inúmeras relações que se estabelecem entre música e dança nas aulas de dança. Tanto professoras quanto alunas e músicos consideram ricas as possibilidades de diálogo entre ambos nas aulas, contudo, com a força da sistematização do ensino, esses diálogos não acontecem, tornando a função do músico de aulas às vezes muito próximas da música gravada, com a vantagem da possibilidade de modificação imediata de certos parâmetros musicais de acordo com as necessidades das professoras.

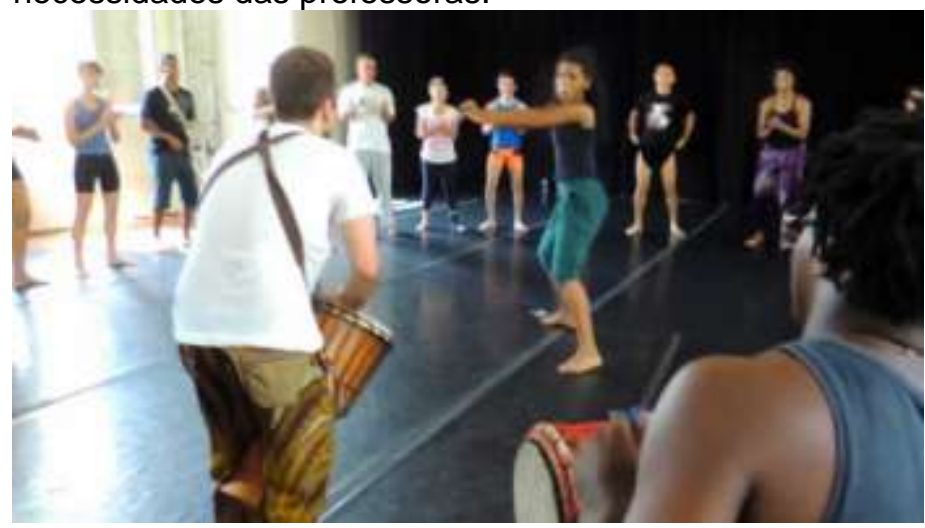

Figura 1. Aula de dança com música ao vivo

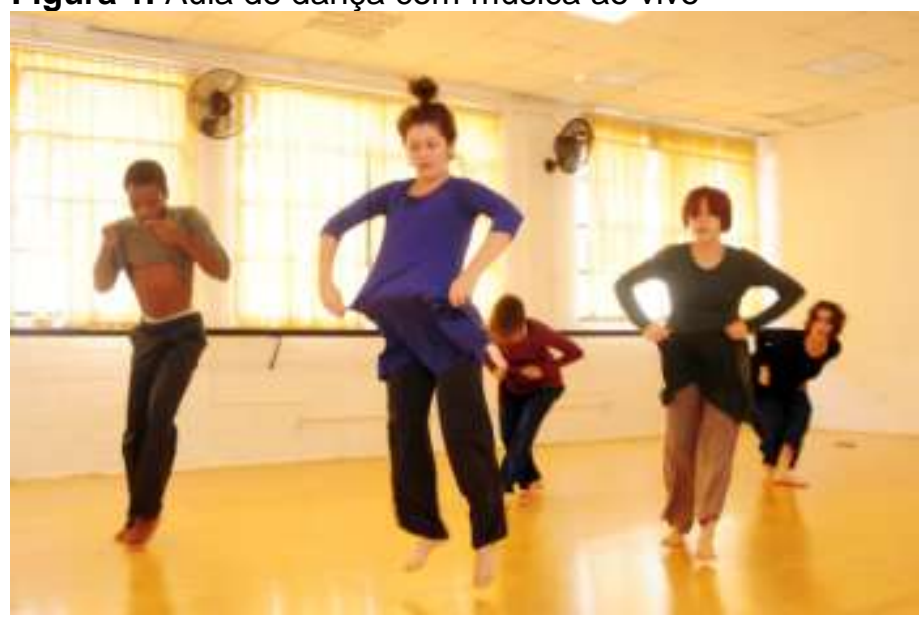

Figura 2. Aula de dança contemporânea

\section{Agradecimentos}

Agradecemos às alunas e professoras da dança que participaram da pesquisa.

Bakhtin, Mikhail. Estética da criação verbal. 4.ed. São Paulo: Martins Fontes, 2003.

Bourdieu, Pierre. O senso prático. Petrópolis: Vozes, 2009.

Lazzarato, Maurizio; Negri, Antonio. Trabalho imaterial.2.ed. Rio de Janeiro: Lamparina, 2013.

SEGNINI, Liliana. Vivências Heterogêneas do trabalho precário. In:

GUIMARÃES, Nadya Araújo; HIRATA, Helena; SUGITA, Curumi (orgs.). Trabalho flexível, empregos precários? São Paulo: Editora da Universidade de São Paulo, 2009, p.169-202. 